\section{BARANG DAN/ATAU JASA OLEH INSTANSI PEMERINTAH}

Instansi Pemerintah ditunjuk sebagai pemotong dan pemungut pajak dalam belanja barang dan/atau jasa untuk keperluan pemerintahan. Dalam buku ini diterangkan mengenai aspek perpajakan pada saat melakukan belanja barang dan/atau jasa yang dilakukan oleh Instansi Pemerintah. Contoh-contoh pertanyaan atau permasalahan yang terkait belanja pemerintahan disampaikan dalam bukuini dengan Bahasa yang mudah dipahami oleh pembaca. Bagaimana pemotongan dan/atau pemungutan pajak saat belanja konsumsi rapat, belanja jasa konstruksi, belanja jasa persewaan kendaraan, pembayaran honorarium, merupakan sebagian permasalahan yang dibahas dalam buku ini.

Buku ini cocok untuk Instansi Pemerintah baik Instansi Pemerintah Pusat, Daerah, maupun Desa, agar dapat melaksanakan pemenuhan kewajiban perpajakan dengan baik. Selain itu, buku ini dapat menjadi referensi bagi pembaca yang ingin mempelajariaspek perpajakan belanja pemerintah.
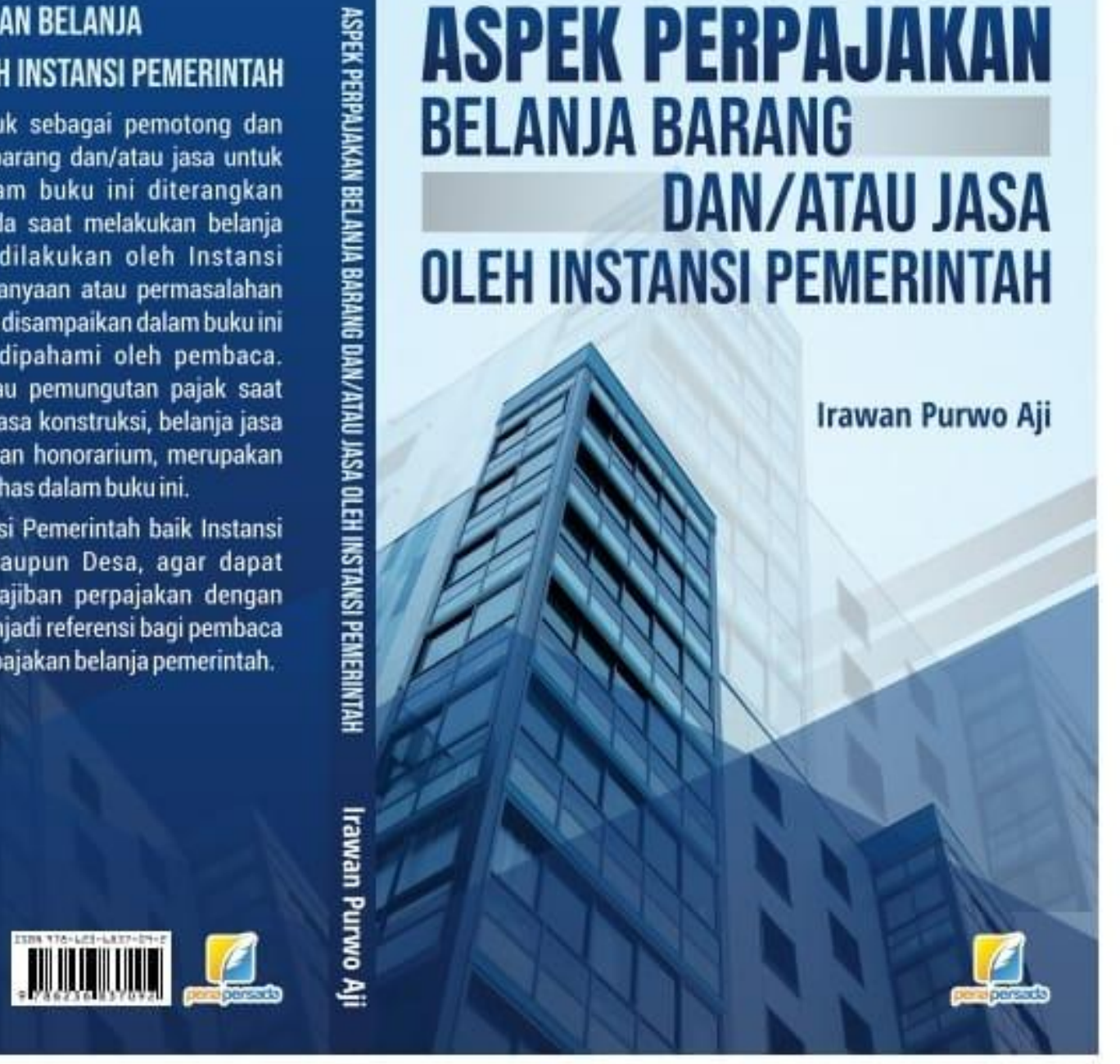


\section{ASPEK PERPAJAKAN \\ BELANJA BARANG DAN/ATAU JASA OLEH \\ INSTANSI PEMERINTAH}

Irawan Purwo Aji

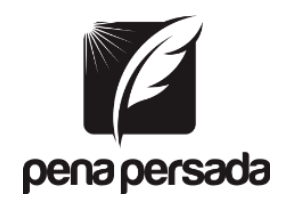

PENERBIT CV. PENA PERSADA 


\title{
ASPEK PERPAJAKAN \\ BELANJA BARANG DAN/ATAU JASA OLEH INSTANSI \\ PEMERINTAH
}

\author{
Penulis: \\ Irawan Purwo Aji
}

ISBN : 978-623-6837-09-2

Design Cover :

Retnani Nur Briliant

Layout :

Fajar T. Septiono

\section{Penerbit CV. Pena Persada \\ Redaksi :}

Jl. Gerilya No. 292 Purwokerto Selatan, Kab. Banyumas

Jawa Tengah

Email : penerbit.penapersada@gmail.com

Website : penapersada.com Phone : (0281) 7771388

\section{Anggota IKAPI}

All right reserved

Cetakan pertama : 2020

Hak Cipta dilindungi oleh undang-undang. Dilarang memperbanyak karya tulis ini dalam bentuk apapun tanpa izin penerbit 


\section{KATA PENGANTAR}

Assalamualaikum warahmatullahi wabarakatuh.

Puji dan syukur dipanjatkan ke hadirat Allah SWT sehingga penulis dapat menyelesaikan buku "Aspek Perpajakan Belanja Barang dan/atau Jasa oleh Instansi Pemerintah".

Berdasarkan PMK-231/PMK.03/2019, Instansi Pemerintah, baik Instansi Pemerintah Pusat, Daerah dan Desa, ditunjuk sebagai pemotong dan pemungut pajak saat melakukan belanja barang dan/atau jasa untuk kegiatan pemerintahan. Dalam pelaksanaannya, masih terdapat Instansi Pemerintah yang belum memahami bagaimana cara melakukan pemotongan dan/atau pemungutan pajak sesuai ketentuan peraturan perpajakan yang berlaku. Dengan belum memahami ketentuan, Instansi Pemerintah tidak dapat melaksanakan pemenuhan kewajiban perpajakan dengan baik.

Buku ini memberikan penjelasan mengenai pemotongan dan/atau pemungutan pajak terkait belanja pemerintah sesuai dengan ketentuan yang berlaku. Contoh-contoh kasus atau pertanyaan terkait dengan aspek perpajakan dalam belanja barang dan/atau jasa yang dilakukan oleh Instansi Pemerintah juga disampaikan dalam buku ini dengan bahasa yang sederhana. Penulis berharap buku ini dapat menjadi panduan bagi Instansi Pemerintah dalam melaksanakan pemenuhan kewajiban perpajakan sebagai pemotong dan pemungut pajak.

Masih banyak hal yang perlu dipelajari terkait aspek perpajakan belanja pemerintah, namun karena berbagai keterbatasan, penulis belum dapat menyampaikan seluruhnya dalam buku ini. Penulis mengharapkan saran dan kritik dari pembaca. Akhir kata, semoga buku ini dapat bermanfaat.

Wassalamualaikum warahmatullahi wabarakatuh.

Penulis

Irawan Purwo Aji 


\section{DAFTAR ISI}

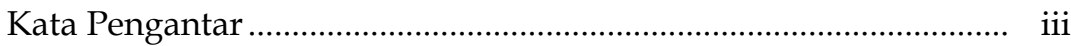

Daftar Isi........................................................................................ iv

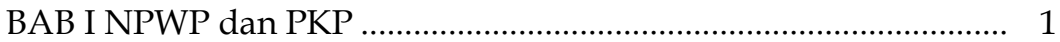

BAB II Penyetoran dan Pelaporan Pajak ............................................ 7

BAB III Pemotongan PPh Pasal 4 ayat (2)...................................... 13

BAB IV Pemotongan PPh Pasal 15 ................................................... 27

BAB V Pemotongan PPh Pasal 21 ...................................................... 33

BAB VI Pemotongan PPh Pasal 22 ................................................. 59

BAB VII Pemotongan PPh Pasal 23 .................................................. 63

BAB VIII Pemotongan PPh Pasal 26 .................................................. 73

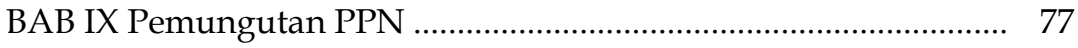

Pertanyaan-pertanyaan terkait Aspek Perpajakan Belanja Barang dan/atau Jasa oleh Instansi Pemerintah .......................................... 89

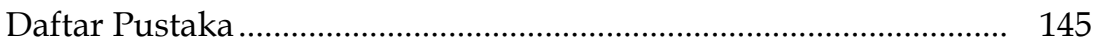

Tentang Penulis............................................................................. 153 


\section{BAB I \\ NPWP dan PKP}

Nomor Pokok Wajib Pajak (NPWP) merupakan nomor yang diberikan kepada Wajib Pajak sebagai sarana dalam administrasi perpajakan yang dipergunakan sebagai tanda pengenal diri atau identitas Wajib Pajak dalam melaksanakan hak dan kewajiban perpajakannya. Bendahara selaku Wajib Pajak juga telah memiliki NPWP sebagai sarana melakukan pemotongan dan/atau pemungutan pajak terkait pembayaran belanja pemerintah.

Namun, dengan berlakunya Peraturan Menteri Keuangan Nomor PMK-231/PMK.03/2019 tentang Tata Cara Pendaftaran dan Penghapusan Nomor Pokok Wajib Pajak, Pengukuhan dan Pencabutan Pengukuhan Pengusaha Kena Pajak, serta Pemotongan dan/atau Pemungutan, Penyetoran, dan Pelaporan Pajak bagi Instansi Pemerintah, atau disebut dengan PMK231/PMK.03/2019, NPWP yang dimiliki oleh Bendahara Pengeluaran, Bendahara Penerimaan, dan/atau Bendahara Desa akan dihapuskan secara jabatan oleh Direktur Jenderal Pajak. Penghapusan tersebut akan ditindaklanjuti oleh Direktur Jenderal Pajak dengan menerbitkan NPWP baru untuk seluruh Instansi Pemerintah secara jabatan. Tanggal terdaftar untuk penerbitan NPWP bagi Instansi Pemerintah secara jabatan tersebut adalah 1 April 2020, akan tetapi penggunaan NPWP Instansi Pemerintah yang baru tersebut berlaku untuk pelaksanaan hak dan/atau kewajiban perpajakan Masa Pajak Juli 2020 dan selanjutnya. Untuk Masa Pajak Juni 2020 dan sebelumnya, Instansi Pemerintah masih dapat menggunakan NPWP Bendahara yang lama.

NPWP Instansi Pemerintah akan diterbitkan secara jabatan bagi instansi pemerintah pusat, instansi pemerintah daerah, dan instansi pemerintah desa, yang melaksanakan kegiatan pemerintahan serta memiliki kewenangan dan tanggung jawab penggunaan anggaran. Instansi Pemerintah Pusat adalah satuan kerja pada kementerian, lembaga pemerintah nonkementerian, 
kesekretariatan lembaga negara, dan kesekretariatan lembaga nonstruktural, termasuk Badan Layanan Umum (BLU), selaku pengguna Anggaran Pendapatan dan Belanja Negara (APBN) yang wajib menyelenggarakan akuntansi dan menyusun laporan keuangan sesuai standar akuntansi pemerintahan. Instansi Pemerintah Daerah adalah satuan kerja perangkat daerah provinsi dan satuan kerja perangkat daerah kabupaten/kota, termasuk Badan Layanan Umum Daerah (BLUD), selaku pengguna Anggaran Pendapatan dan Belanja Daerah (APBD) yang wajib menyelenggarakan akuntansi dan menyusun laporan keuangan sesuai standar akuntansi pemerintahan. Instansi Pemerintah Desa adalah unit organisasi penyelenggara pemerintahan desa selaku pengguna Anggaran Pendapatan dan Belanja Desa (APBDes) yang wajib menyelenggarakan akuntansi dan menyusun laporan keuangan sesuai standar akuntansi pemerintahan.

Selain NPWP, bagi Instansi Pemerintah yang melakukan penyerahan Barang Kena Pajak (BKP) dan/atau Jasa Kena Pajak (JKP) akan dikukuhkan sebagai Pengusaha Kena Pajak (PKP) Instansi Pemerintah secara jabatan oleh Direktur Jenderal Pajak. Ketentuan ini tidak berlaku apabila Instansi Pemerintah memenuhi kriteria pengusaha kecil. Pengusaha kecil merupakan pengusaha yang selama 1 (satu) tahun buku melakukan penyerahan Barang Kena Pajak dan/atau Jasa Kena Pajak dengan jumlah peredaran bruto dan/atau penerimaan bruto tidak lebih dari Rp4.800.000.000,00 (empat miliar delapan ratus juta rupiah).

Instansi Pemerintah yang telah menerima NPWP dan/atau PKP Instansi Pemerintah diwajibkan untuk melakukan permohonan perubahan data, aktivasi Electronic Filing Identification Number (EFIN), permohonan Sertifikat Elektronik, dan aktivasi akun PKP bagi Instansi Pemerintah yang telah dikukuhkan sebagai PKP. Permohonan perubahan data diajukan oleh Instansi Pemerintah ke Kantor Pelayanan Pajak (KPP) terdaftar dengan dilampiri:

1. fotokopi dokumen penunjukan sebagai:

a. kepala Instansi Pemerintah Pusat, Kuasa Pengguna Anggaran, atau pejabat yang melaksanakan fungsi tata 
usaha keuangan pada Instansi Pemerintah Pusat, untuk Instansi Pemerintah Pusat;

b. kepala Instansi Pemerintah Daerah atau pejabat yang melaksanakan fungsi tata usaha keuangan pada satuan kerja perangkat daerah untuk Instansi Pemerintah Daerah; atau

c. kepala desa atau perangkat desa yang melaksanakan pengelolaan keuangan desa berdasarkan keputusan kepala desa untuk Instansi Pemerintah Desa;

2. fotokopi dokumen penunjukan Bendahara Pengeluaran, Bendahara Penerimaan, dan/atau Kepala Urusan Keuangan Desa; dan

3. fotokopi Kartu Tanda Penduduk orang pribadi yang ditunjuk sebagaimana dimaksud pada angka 1 dan angka 2.

Untuk dapat memanfaatkan layanan perpajakan secara elektronik, Instansi Pemerintah harus mengajukan permohonan Sertifikat Elektronik. Sertifikat Elektronik merupakan sertifikat yang bersifat elektronik yang memuat Tanda Tangan Elektronik dan identitas yang menunjukan status subjek hukum para pihak dalam transaksi elektronik yang dikeluarkan oleh Direktorat Jenderal Pajak (DJP) atau penyelenggara sertifikasi elektronik. Tanda Tangan Elektronik adalah tanda tangan yang terdiri atas informasi elektronik yang dilekatkan, terasosiasi atau terkait dengan informasi elektronik lainnya yang digunakan sebagai alat verifikasi dan autentikasi. Ketentuan dalam pengajuan permohonan Sertifikat Elektronik Instansi Pemerintah adalah:

1. permintaan Sertifikat Elektronik diajukan dengan mengisi, menandatangani, dan menyampaikan Formulir Permintaan Sertifikat Elektronik oleh:

a. kepala Instansi Pemerintah Pusat, kuasa pengguna anggaran, atau pejabat yang melaksanakan fungsi tata usaha keuangan pada Instansi Pemerintah Pusat, untuk Instansi Pemerintah Pusat;

b. kepala Instansi Pemerintah Daerah atau pejabat yang melaksanakan fungsi tata usaha keuangan pada satuan 
kerja perangkat daerah, untuk Instansi Pemerintah Daerah; atau

c. kepala desa atau perangkat desa yang melaksanakan pengelolaan keuangan desa berdasarkan keputusan kepala desa, untuk Instansi Pemerintah Desa;

2. pejabat diatas menunjukkan asli dan menyerahkan fotokopi dokumen berupa:

a. penunjukan sebagai:

1) kepala Instansi Pemerintah Pusat, kuasa pengguna anggaran, atau pejabat yang melaksanakan fungsi tata usaha keuangan pada Instansi Pemerintah Pusat, untuk Instansi Pemerintah Pusat;

2) kepala Instansi Pemerintah Daerah atau pejabat yang melaksanakan fungsi tata usaha keuangan pada satuan kerja perangkat daerah, untuk Instansi Pemerintah Daerah; atau

3) kepala desa atau perangkat desa yang melaksanakan pengelolaan keuangan desa berdasarkan keputusan kepala desa, untuk Instansi Pemerintah Desa;

b. dokumen identitas diri orang pribadi yang ditunjuk; dan

c. fotokopi NPWP orang pribadi yang ditunjuk; dan

3. pejabat melakukan kegiatan untuk verifikasi dan autentikasi identitas.

Aktivasi EFIN dan akun PKP dapat dilakukan melalui saluran yang ditunjuk oleh DJP. Aktivasi ini penting dilakukan agar Instansi Pemerintah dapat menggunakan layanan perpajakan secara elektronik.

Instansi Pemerintah dapat mengajukan penghapusan NPWP jika dalam keadaan:

1. tidak lagi beroperasi sebagai Instansi Pemerintah;

2. pembubaran Instansi Pemerintah yang disebabkan karena penggabungan Instansi Pemerintah;

3. tidak mendapat alokasi anggaran pada tahun anggaran berikutnya; atau

4. tidak lagi beroperasi yang diakibatkan oleh sebab lain. 
Pencabutan pengukuhan PKP dilaksanakan terhadap Instansi Pemerintah yang tidak lagi memenuhi kriteria sebagai PKP. Penghapusan NPWP bagi PKP Instansi Pemerintah diikuti dengan pencabutan pengukuhan PKP.

Referensi:

UU KUP

PMK-197/PMK.03/2013

PMK-231/PMK.03/2019

Per-04/PJ/ 2020

Kep-237/PJ/2020

SE-12/PJ/2020 


\title{
ASPEK PERPAJAKAN BELANJA BARANG DAN/ATAU JASA OLEH INSTANSI PEMERINTAH
}

\author{
Irawan Purwo Aji
}




\section{BAB II}

Penyetoran dan Pelaporan Pajak

Instansi Pemerintah melalui PMK-231/PMK.03/2019 ditunjuk sebagai pemotong dan/atau pemungut Pajak Penghasilan (PPh) serta sebagai pemungut Pajak Pertambahan Nilai (PPN) atau PPN dan Pajak Penjualan atas Barang Mewah (PPnBM) dalam melakukan belanja barang dan/atau jasa untuk memenuhi kegiatan pemerintahan. Pajak Penghasilan yang dipotong dan/atau dipungut adalah:

1. PPh Pasal 4 ayat (2);

2. PPh Pasal 15;

3. PPh Pasal 21;

4. PPh Pasal 22;

5. PPh Pasal 23; dan

6. PPh Pasal 26.

Penjelasan mengenai pemotongan dan/atau pemungutan jenis-jenis pajak tersebut akan dibahas dalam bab berikutnya.

Setelah melakukan pemotongan dan/atau pemungutan pajak, Instansi Pemerintah harus menyetorkannya pajak yang telah dipotong dan/atau dipungut ke Kas Negara. Penyetoran pajak tersebut dilakukan melalui Bank/Pos Persepsi dengan menggunakan Kode Billing. Kode Billing adalah kode identifikasi yang diterbitkan melalui Sistem Billing DJP atas suatu jenis pembayaran atau penyetoran pajak.

Penyetoran pajak yang telah dipotong dan/atau dipungut disetorkan ke Kas Negara dapat melalui:

1. teller Bank/Pos Persepsi;

2. Anjungan Tunai Mandiri (ATM);

3. internet banking;

4. mobile banking;

5. Electronic Data Capture (EDC); atau

6. sarana lainnya. 
Penyetoran pajak dilakukan dengan mencantumkan Kode Akun Pajak (KAP) dan Kode Jenis Setoran (KJS) yang sesuai dengan jenis pajak yang akan disetorkan. Satu setoran pajak digunakan untuk 1 (satu) KAP dan 1 (satu) KJS. Daftar KAP/KJS akan dibahas dalam bab selanjutnya.

Setelah melakukan penyetoran pajak, Instansi Pemerintah akan memperoleh Bukti Penerimaan Negara (BPN). BPN yang diperoleh tersebut dapat berupa:

1. dokumen bukti pembayaran yang diterbitkan Bank/Pos Persepsi, untuk pembayaran atau penyetoran melalui teller dengan Kode Billing;

2. struk bukti transaksi, untuk pembayaran melalui ATM atau EDC;

3. dokumen elektronik, untuk pembayaran atau penyetoran melalui internet banking atau mobile banking; atau

4. teraan elemen data BPN pada SSP untuk pembayaran melalui teller Bank/Pos Persepsi dengan menggunakan SSP.

BPN termasuk cetakan, salinan, dan fotokopinya, kedudukannya disamakan dengan Surat Setoran Pajak (SSP) dalam rangka pelaksanaan ketentuan peraturan perundangundangan perpajakan. Di dalam BPN tercantum sebagai berikut:

1. Nomor Transaksi Penerimaan Negara (NTPN);

2. Nomor Transaksi Bank (NTB) atau Nomor Transaksi Pos (NTP);

3. Kode Billing;

4. Nomor Pokok Wajib Pajak (NPWP);

5. nama Wajib Pajak;

6. alamat Wajib Pajak, kecuali untuk BPN yang diterbitkan melalui ATM dan EDC;

7. Nomor Objek Pajak (NOP), bila ada;

8. Kode Akun Pajak;

9. Kode Jenis Setoran;

10. Masa Pajak;

11. Tahun Pajak;

12. nomor ketetapan pajak, bila ada; 
13. uraian pembayaran, bila ada;

14. NPWP penyetor, bila ada;

15. nama penyetor, bila ada;

16. tanggal bayar; dan

17. jumlah nominal pembayaran.

Jangka waktu penyetoran pajak atas pajak yang telah dipotong dan/atau dipungut oleh Instansi Pemerintah diatur dalam PMK-231/PMK.03/2019. Instansi Pemerintah Pusat dan Instansi Pemerintah Daerah wajib menyetorkan PPh dan PPN atau PPN dan PPnBM yang telah dipotong dan/atau dipungut:

1. paling lama 7 (tujuh) hari setelah tanggal pelaksanaan pembayaran dengan mekanisme Uang Persediaan (UP) sesuai ketentuan peraturan perundang-undangan di bidang perpajakan; atau

2. pada hari yang sama dengan pelaksanaan pembayaran dengan mekanisme Langsung (LS) sesuai ketentuan peraturan perundang-undangan di bidang perpajakan.

Sedangkan bagi Instansi Pemerintah Desa wajib menyetorkan PPh dan PPN atau PPN dan PPnBM yang telah dipotong dan/atau dipungut paling lama tanggal 10 (sepuluh) bulan berikutnya setelah pelaksanaan pembayaran.

Setelah melakukan penyetoran pajak, Instansi Pemerintah harus melakukan pelaporan pajak dengan menggunakan Surat Pemberitahuan (SPT) Masa. Pelaporan SPT Masa atas belanja pemerintah dilakukan paling lama 20 (dua puluh) hari setelah Masa Pajak berakhir.

Bagi Instansi Pemerintah yang telah dikukuhkan sebagai PKP, ketentuan penyetoran PPN atau PPN dan PPn BM serta pelaporan SPT Masa PPN mengikuti ketentuan untuk PKP pada umumnya. Sebagai PKP Instansi Pemerintah harus menyetorkan PPN atau PPN dan PPn BM yang terutang dalam suatu masa pajak paling lama akhir bulan berikutnya setelah Masa Pajak berakhir dan sebelum SPT Masa PPN disampaikan. Pelaporan SPT Masa 
PPN bagi PKP Instansi Pemerintah dilakukan paling lama akhir bulan berikutnya setelah masa pajak berakhir.

Apabila jangka waktu penyetoran pajak dan pelaporan SPT bertepatan dengan hari libur, yaitu hari Sabtu, hari Minggu, hari libur nasional, atau hari yang diliburkan oleh pemerintah, maka penyetoran pajak dan pelaporan pajak dapat dilakukan paling lambat hari kerja berikutnya.

Jangka Waktu Penyetoran dan Pelaporan Pajak

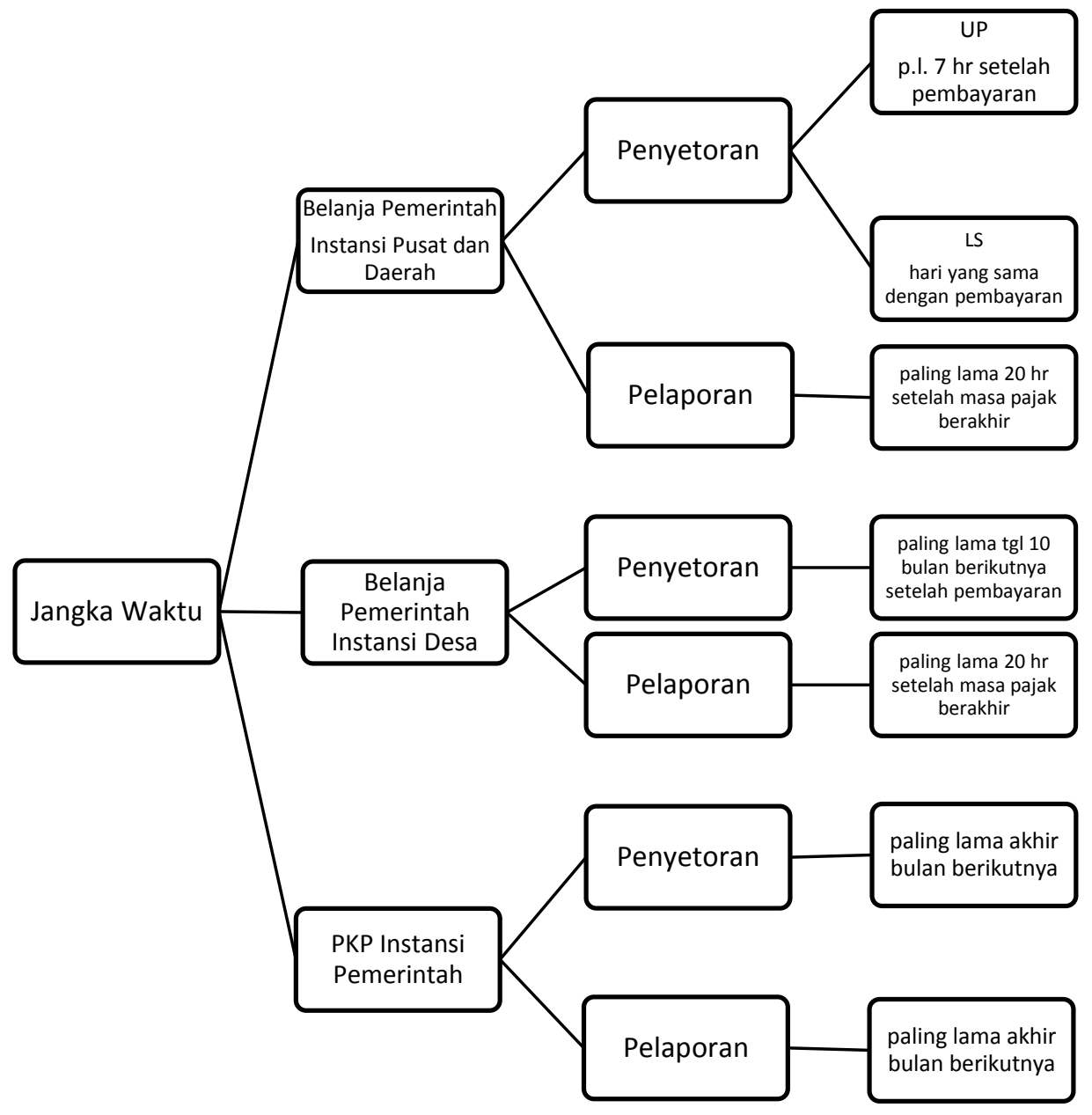


Referensi:

UU KUP

PMK-242/PMK.03/2014

PMK-243/PMK.03/2014

PMK-231/PMK.03/2019

Per-05/PJ/ 2017 


\title{
ASPEK PERPAJAKAN BELANJA BARANG DAN/ATAU JASA OLEH INSTANSI PEMERINTAH
}

\author{
Irawan Purwo Aji
}

